\title{
PALEOBATHYMETRIC EVOLUTION OF THE EARLY LATE MIOCENE DEPOSITS OF THE PRE-APULIAN ZONE, LEVKAS ISLAND, IONIAN SEA
}

\section{Drinia H. ${ }^{1}$, Antonarakou A. ${ }^{1}$, Kontakiotis G. ${ }^{1}$, Tsaparas N. ${ }^{1}$, Segou M. ${ }^{2}$, and Karakitsios V. ${ }^{1}$}

\begin{abstract}
${ }^{1}$ National and Kapodistrian University of Athens, Faculty of Geology and Geoenvironment, Department of Hist.Geology - Paleontology, cntrinia@geol.uoa.gr,aantonar@geol.uoa.gr, gkontak@geol.uoa.gr,ntsapar@geol.uoa.gr,vkarak@geol.uoa.gr

${ }^{2}$ National and Kapodistrian University of Athens, Faculty of Geology and Geoenvironment, Department of Geophysics-Geothermy,msegou@geol.uoa.gr
\end{abstract}

\begin{abstract}
The Manassi section in Levkas Island belongs to the Pre-Apulian (Paxos) zone, the most external domain of the Hellenic realm. Its Early Tortonian sediments contain a rich foraminiferal fauna dominated, in numbers of individuals, by planktic species. Its benthic foraminiferal assemblage is characterized by a high number of taxa, with low numbers of individuals. Their study provides a basis for interpreting the paleobathymetry of the basin.

The Manassi section represents deposition in upper to lower bathyal depths, during a period of intense tectonic activity. Downslope transport of fauna by turbidity currents partly overprints the signal of paleobathymetrically-diagnostic foraminifera distribution. The recognition of allochthonous taxa is used, together with $\% P$, to identify turbidite beds intercalated with in-situ marly sediments.

The micropaleontological and paleobathymetrical analyses of the studied sediments indicate that these correspond to distal atypical flysch deposited in the foredeep depozone of the most external domain (Pre-Apulian zone) of the Hellenide foreland basin.
\end{abstract}

Key words: benthic foraminifera, paleobathymetry, Tortonian, Pre-Apulian zone, Mediterranean.

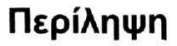

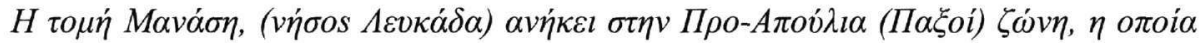

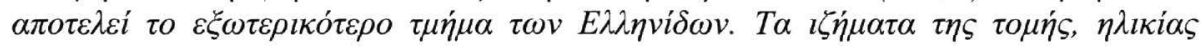

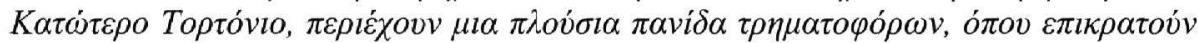

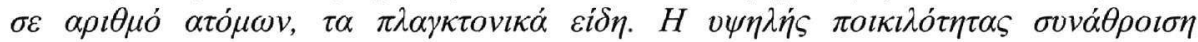

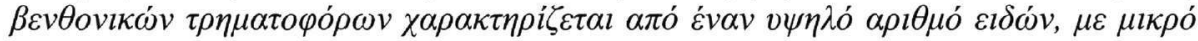

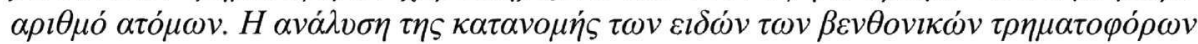

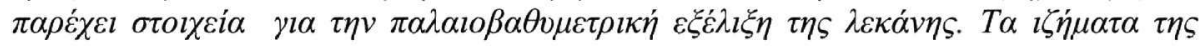

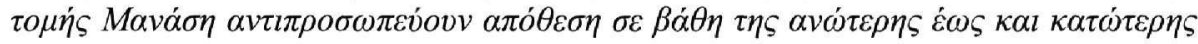

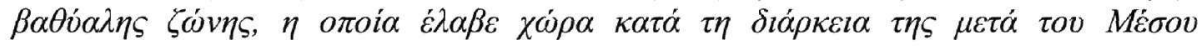




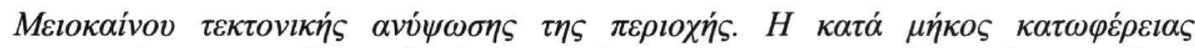

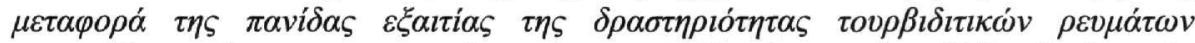

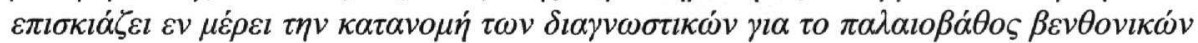

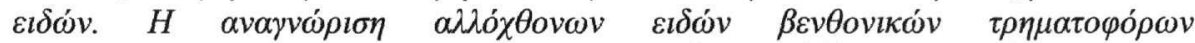

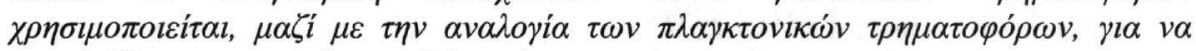

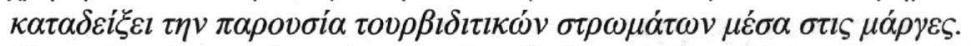

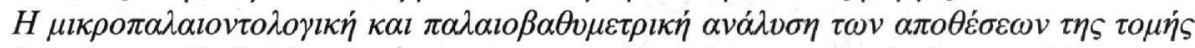

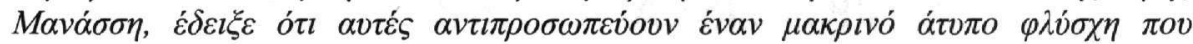

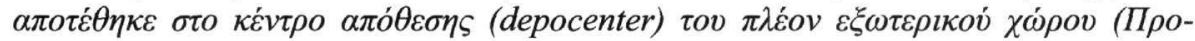

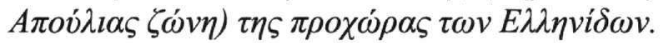

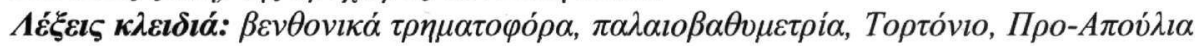

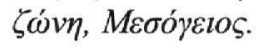

\section{Introduction}

A common goal in basin analysis is the assessment of paleobathymetry for use to interpret depositional environments, subsidence history and other aspects of basin evolution. The Middle Miocene foreland basin of Levkas island, Ionian Sea, needs considerable study both for its wellexposed outcrops of deep marine turbiditic strata and as an example of its sedimentary infill. Such studies are considerably hampered, however, by the lack of knowledge of paleobathymetry. The magnitude of uncertainty in paleobathymetric estimates could prevent a correct interpretation of subsidence analysis in such deep-water deposits.

Micropaleontologists have developed several methods to estimate paleodepths, in addition to methods based on the comparative abundance of planktic and benthic foraminifera. For example Culver (1988) documented the bathymetric distribution of some benthic foraminifera in the modern-day Gulf of Mexico, and used these to estimate paleodepths in some Cenozoic sequences in the same region. Murray and Alve (2000) found an overall trend towards an increase in benthic foraminiferal biodiversity with paleodepth. Van der Zwaan et al. (1990) determined a regression for the relationship between bathymetry and the percentage of planktic foraminifera with respect to the total fossil foraminiferal population $(\% \mathrm{P})$, based on present day bathymetric transects:

$$
\operatorname{Depth}(m)=e^{3.58718+(0.03534 * \% P)}
$$

where the plankton fraction $\% \mathrm{P}=100 * \mathrm{P} /(\mathrm{P}+\mathrm{B}-\mathrm{S})$, and $\mathrm{P}$ is the amount of planktic foraminifera, $\mathrm{B}$ is the amount of benthic foraminifera and $\mathrm{S}$ is the amount of environmental stress markers, e.g. species of benthic foraminifera that can tolerate low oxygen concentrations [original list of Van der Zwaan et al. (1990) modified by Van Hinsbergen et al. (2005)].

However, the most widely applied methodology for assessing paleobathymetry is the analysis of benthic foraminiferal biofacies. In fact, benthic foraminifera have proved to be useful bathymetric indicators. Recent studies on modern faunas demonstrated that the faunal composition is strongly related to organic matter flux rates and dissolved oxygen concentrations in the bottom and pore water (e.g. Corliss 1985, Gooday 1994, Jorissen et al. 1995). In oceanic environments both parameters exhibit strong depth-dependent gradients. Consequently, certain benthic foraminiferal faunas are restricted to distinct bathymetric intervals. In particular, continental margins are characterized by a stenobathic distribution of many benthic foraminifera (e.g. Schmiedl et al. 1997).

In the present study, the overall nature of the benthic foraminiferal assemblages is examined to prove the validity of paleodepth estimations obtained computed using the percentage of planktic foraminifera, in part of the Miocene age deep sea sediments of Levkas Island. 


\section{Geological Setting}

Levkas Island belongs to the Ionian Islands which are located in the west segment of the Hellenic Arc, the most active plate margin of the Mediterranean region (e.g. McKenzie 1978). The tectonic setting of the wider area is determined by the continental collision between northwestern Greece in the east and the Apulian platform in the west, as well as by the subduction of the African plate under the Aegean microplate along the active Hellenic Arc in the southwest. The Ionian Islands are situated in a transitional zone between the northwestern end of this active subsidence and the continental collision in the north.

The main tectonic structure of this transitional area is the Kephallinia Fault Zone (KFZ), which represents the active boundary between the SW-moving Aegean microplate and the Apulian platform. Based on data from Durmeijer et al. (1999) and Gautier et al. (1999) the age of the onset of the activity of KFZ could be estimated to a possible maximum age of the Pliocene-Pleistocene boundary. Many neotectonic active faults, striking to the NNE-SSW or E-W direction cross-cut the island (e.g. Cushing 1985).

Levkas island is built up mainly by Alpine Mesozoic-Cenozoic sedimentary rocks belonging to the external units of the Hellenides, the Pre-Apulian (Paxos) zone and the Ionian zone (Fig. 1; Bornovas 1964, IGRS-IFP 1966, Cushing 1985), separated from one another by a major westdirected thrust fault (Aubouin 1957, Jacobshagen 1986). This thrust boundary is marked by evaporite intrusion suggesting that contractional deformation was the most important structural control of orogenesis in Western Greece (Karakitsios and Rigakis in press).

The Pre-Apulian zone corresponds to the most external domain of the Hellenic realm. It has been traditionally considered as a relatively uniform Mesozoic - Cenozoic carbonate transitional domain, between the Apulian platform and the Ionian basin (BP 1971, Karakitsios 1995). The general setting is complicated by strong tectonic deformation, including crustal extension, collision, and flexural subsidence, with undetermined amounts of shortening and block rotation (Karakitsios and Rigakis in press). Indeed, the outcropping successions differ in stratigraphic completeness, sedimentary development and faunal/floral content.

The depositional sequence in the Pre-Apulian zone begins with Triassic to Bajocian limestones, containing intercalations of black shales and anhydrite beds (borehole data, ESSO Hel. 1960). The lowest stratigraphic outcrops, located in Levkas Island, comprise Lower Jurassic dolomites and Middle Jurassic cherts and bituminous shales (Bornovas 1964, BP 1971). The Upper Jurassic consists of white chalky limestones and dolomite intercalations, with rare cherts and organiccarbon-rich black shales, containing planktic foraminifera. Lower Cretaceous limestones and dolomites outcrop only in Kephallonia Island, and are considered less pelagic in comparison to the Ionian facies of the same age. During the Campanian-Maastrichtian the platy limestones gradually become chalky with thin layers of argillaceous schists. They contain planktic foraminifera together with Rudists' fragments indicating the presence of intra-platform basins, characterizing the slope between the Apulian platform and the Ionian basin (Nikolaou 1986, Karakitsios and Rigakis in press).

The Paleocene formations consist of micritic limestones with planktic foraminifera (BP 1971). Intense tectonic activity, resulting in the differentiation of the Pre-Apulian zone, into relatively deep and shallow (sometimes emerged) areas, is deduced by sporadic hiatuses in between Paleocene and Late Cretaceous, described by Mirkou (1974). The Lower Eocene sequence comprises pelagic limestones with marl intercalations, whilst the Upper Eocene formations consist of reefal, unbedded limestones, with Algae, Bryozoans, Corals, Echinoids, and large foraminifera. Oligocene sediments were deposited in small basins (tectonic grabens) in between emerged areas, which were locally eroded. This setting can be attributed to the intense tectonic instability, which persisted throughout the Oligocene. During the Oligocene-Aquitanian, the intense diversification of foraminiferal assemblages (Accordi et al. 1998) suggests the presence of flexural subsiding 
foreland basins (Karakitsios and Rigakis in press). In the late Early Miocene, progressive deepening ensued, with the demise of the former carbonate slope.
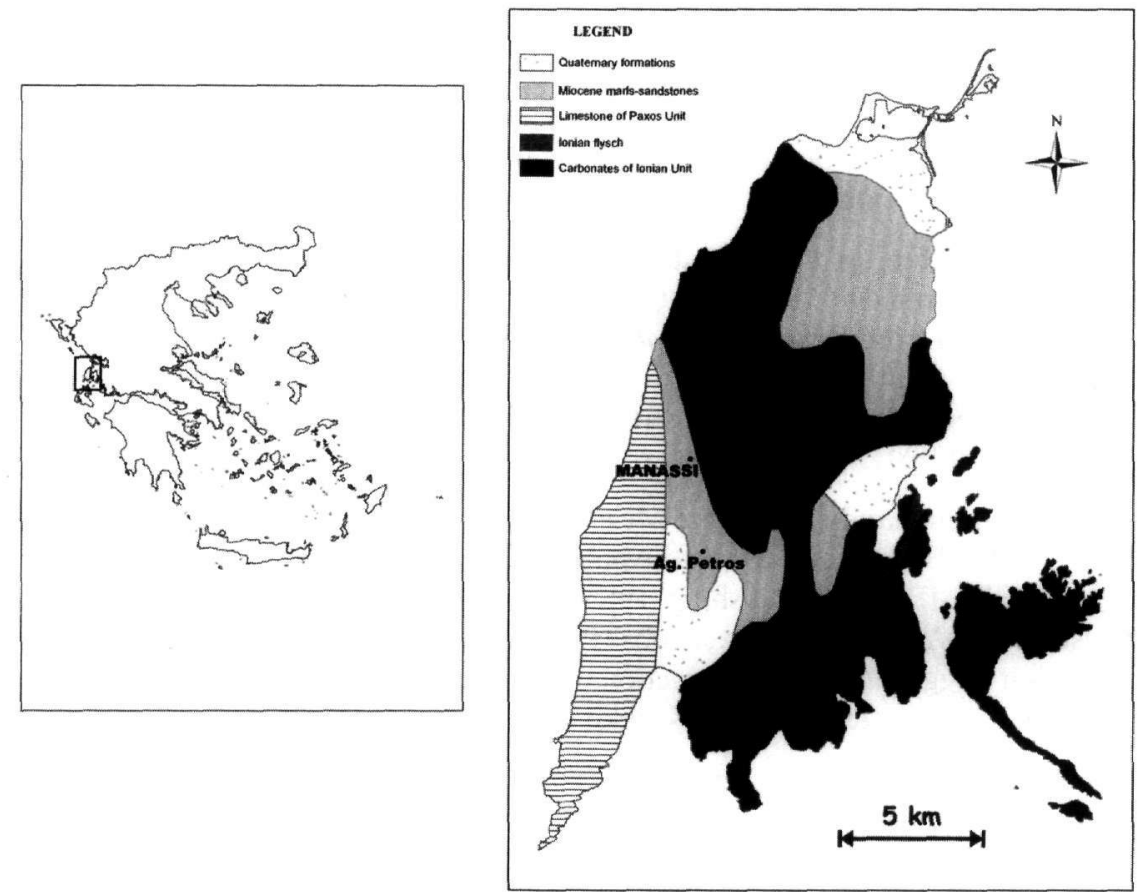

Figure 1 - Simplified geological map of Levkas island indicating the location of the studied section (after Rondoyianni-Tsiambaou 1997)

\section{Study Location and Methods}

This research deals with a more detailed study on paleobathymetry of a Miocene section (Manassi section) which belongs to the pre-Apulian zone and is located in the southwestern part of Levkas island (Fig. 1).

The Oligocene-Miocene deposits in this area conformably overlie Eocene limestones in the west (de Mulder 1975). Finely-bedded, pelagic limestones of Eocene age are overlain by a relatively thin succession of detrital, neritic limestones, passing upwards into at least 400-500 m of marls and clays, which may reach as high as the Upper Miocene (Bizon 1967).

The Manassi Section is located on the eastern slope of a N-S oriented valley. The studied succession consists of blue grey marls and clays with some fine grained sandstone interbeds. The intercalations of these thin, clastic beds and especially of positively graded sandstones in the studied succession reflect the influence of density currents, which supplied coarser material from a distant hinterland (de Mulder 1975).

The $25 \mathrm{~m}$-thick section was measured and sampled at 0.5 to $1 \mathrm{~m}$ intervals. For the faunal analysis 26 samples (391-1 to 391-26) were taken (Fig. 2). Samples were washed over a $63 \mu \mathrm{m}$ sieve and subsequently the coarse fraction was dry sieved over $125 \mu \mathrm{m}$ sieve. The fraction $>125 \mu \mathrm{m}$ was then investigated for its benthic foraminiferal content. The picked planktonic specimens were counted and their (\%P) was computed. Biostratigraphic attribution is based on the standard biozonal schemes of Iaccarino (1985) according to the absolute ages from Hilgen et al. (2000) and Foresi et al. (2002). 
The total number of planktic (PFN) and benthic (BFN) foraminifera per gram was calculated by extrapolating the number of specimens in the split to the whole residue.

In order to calculate the changing paleobathymetry the following factors were identified:

Diversities were determined following the Shannon-Wiener index (e.g. Buzas and Gibson 1969). In addition, ratios between planktic (P) and benthic (B) foraminifera were calculated applying the formula $\mathrm{P} /(\mathrm{P}+\mathrm{B})$. The $\mathrm{P} / \mathrm{B}$ ratios were integrated with marker benthic foraminifera in order to determine paleobathymetry.

To assess the depositional depth of the studied marine sediments, the general relationship between the fraction of planktic foraminifera with respect to the total foraminiferal population (\%P) and depth of Van der Zwaan et al. (1990) was used, following sample selection and counting procedures described by van Hinsbergen et al. (2005).

\section{MANASSI SECTION}

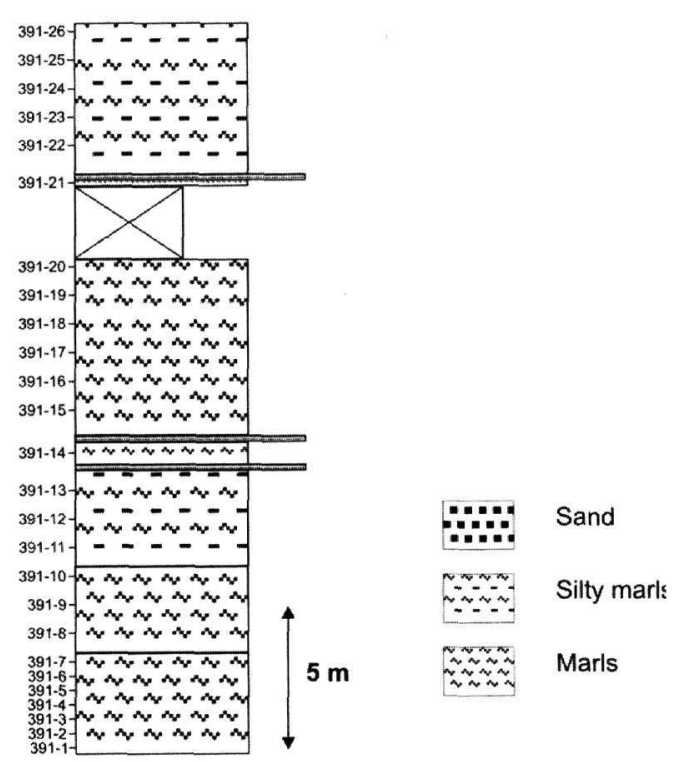

\section{Figure 2 - Lithostratigraphical column of the studied section}

The following depth zonation (McDougall, 1985) was used: inner shelf $=0-50 \mathrm{~m}$, outer shelf $=50$ $150 \mathrm{~m}$, upper bathyal $=150-500 \mathrm{~m}$, upper middle bathyal $=500-1500 \mathrm{~m}$, lower middle bathyal $=1500-2000 \mathrm{~m}$, lower bathyal $=2000-3500 \mathrm{~m},>3500 \mathrm{~m}=$ abyssal.

\section{Biostratigraphy}

The planktonic foraminiferal analysis was carried out on the total of samples. Preservation was generally good, although at times was poor. The biostratigraphic results were based on the qualitative analysis of planktonic foraminifera, analyzed at the species level. Their specific identifications were conducted according to reference publications (Dermitzakis 1978, Iaccarino 1985, Hilgen et al. 2000, Foresi et al. 2002). For the biostratigraphic analysis we only considered the appearance/disappearance of marker species and paracme/acme intervals of selected taxa according to Foresi et al. (2002).

The qualitative analysis revealed 14 planktonic foraminifera categories: Paragloborotalia siakensis, Globigerinoides obliquus obliquus, Globorotalia menardii-preamenardii, Catapsydrax parvulus, Neogloboquadrina atlantica praeatlantica, P. partimlabiata and N. acostaensis. The coiling direction of the neogloboquadriniids was investigated separately because of their biostratigraphic value.

G. obliquus obliquus is present in all the samples and no specimens of G. subquadratus were observed. The last common occurrence (LCO) of G. subquadratus, has been dated in the Mediterranean at 11.54 and 11.58 Ma (Hilgen et al. 2000, 2003, Lirer et al. 2002) and at same time (11.54 Ma according to Hilgen et al. 2000, 2003, Lirer et al. 2002), the first regular occurrence (FRO) of G. obliquus is recorded. This event coincides with the end of the first influx of the neogloboquadrinids (FO of neogloboquadrinids $11.78 \mathrm{Ma}$ ), (Hilgen et al. 2000, 2003, Foresi et al. 2002). Above this level N. acostaensis occurs in low percentages. 
In our record few specimens of $N$. acostaensis are recorded (2-5\%) with random (left and right) coiling direction. $N$. antlantica praeantlantica is also present having the same distributional pattern of $N$. acostaensis. A paracme interval in the distribution range of neogloboquadriniids has been recorded in Mediterranean and dated at 11.54 -11.21 Ma (Foresi et al. 2002). These dates coincide with the LCO of G. subquadratus and the LO of $P$. siakensis respectively (Iaccarino et al. 2004, Foresi et al. 2002, Hilgen et al. 2003). In the same interval C. parvulus is abundant (Foresi et al., 2002). In the studied section the same pattern of $C$. parvulus is observed.

$P$. siakensis left coiled is abundant from the base of the section upward. The last occurrence of this species has been dated at 11.21 Ma (Hilgen et al. 2000, Caruso et al. 2002, Di Stefano et al. 2002, Foresi et al. 2002, Lirer et al. 2004, Iaccarino et al. 2004). Catapsydarx parvulus is present in several samples throughout the section. The last occurrence of this species in Mediterranean is reported at $9.91 \mathrm{Ma}$ (Hilgen et al. 2000).

Consequently, according to the biostratigraphical criteria such as the distributional pattern of neogloboquadriniids, the regular occurrence of $G$. obliquus obliquus and the presence of $P$. siakensis in all the samples, the section covers the time interval between 11.54 and $11.2 \mathrm{Ma}$, having a lower Tortonian age, just above the Serravallian/Tortonian boundary astronomically dated at $11.6 \mathrm{Ma}$ (Hilgen et al. 2005).

\section{Benthic Foraminifera Species}

Of the 26 samples, only one was barren of benthic foraminifera. It is sample 391-26 which contains high fractions of quartz and rock fragments, which probably derived from downslope transport. Four samples yielded fewer than 200 benthics (391-21, 105 total foraminifera only, 39123, 180 foraminifera only, 391-24, 183 foraminifera only and 391-25, 73 foraminifera only). However, paleodepths for these samples were estimated.

One hundred and sixty nine species and species groups of benthic foraminifera were identified in the 25 samples studied. The primary taxonomic references are given in Ellis and Messina (1940 and supplements).

Fig. 3 shows the frequency of the dominant benthic species in the samples. The most abundant species recovered from the section were Siphonina reticulata, Cibicidoides kullenbergi, Melonis barleeanus, C. italicus. These taxa abundantly and persistently occur throughout the section along with Globocassidulina subglobosa, Gyroidinoides neosoldanii and Uvigerina semiornata rutila. In the upper part of the section, clearly transported shallow water taxa co-occur with deep water species. In these cases it can be clearly inferred that the shallow water taxa have been dislodged downslope into deeper waters, through transport or turbidity activity.

\section{Paleobathymetry}

\subsection{Analysis of \%P planktic foraminifera}

The result of total planktic foraminiferal (PFN) fauna performed in this study is shown in Fig.4, together with BFN trends. With the exception of samples 391-1 to 391-3 and 391-20, the planktic abundance $(\mathrm{P} / \mathrm{P}+\mathrm{B})$ in all observed Manassi samples is greater than $90 \%$. According to Van der Zwaan et al. (1990) these data suggest an average water depth of about $1000 \mathrm{~m}$. Moreover, the PFN strongly fluctuates between 1330 specimens per gram and 78.500 specimens per gram; whereas BFN remains relatively stable exhibiting low values (Fig. 4). According to Mendes et al. (2004), the BFN is inversely related with water depth. Slightly increased BFN in the lowermost part of the section (sample 391-3) indicates that at this stratigraphic level bottom water conditions have been generally more favorable for the production of benthic foraminifera. 


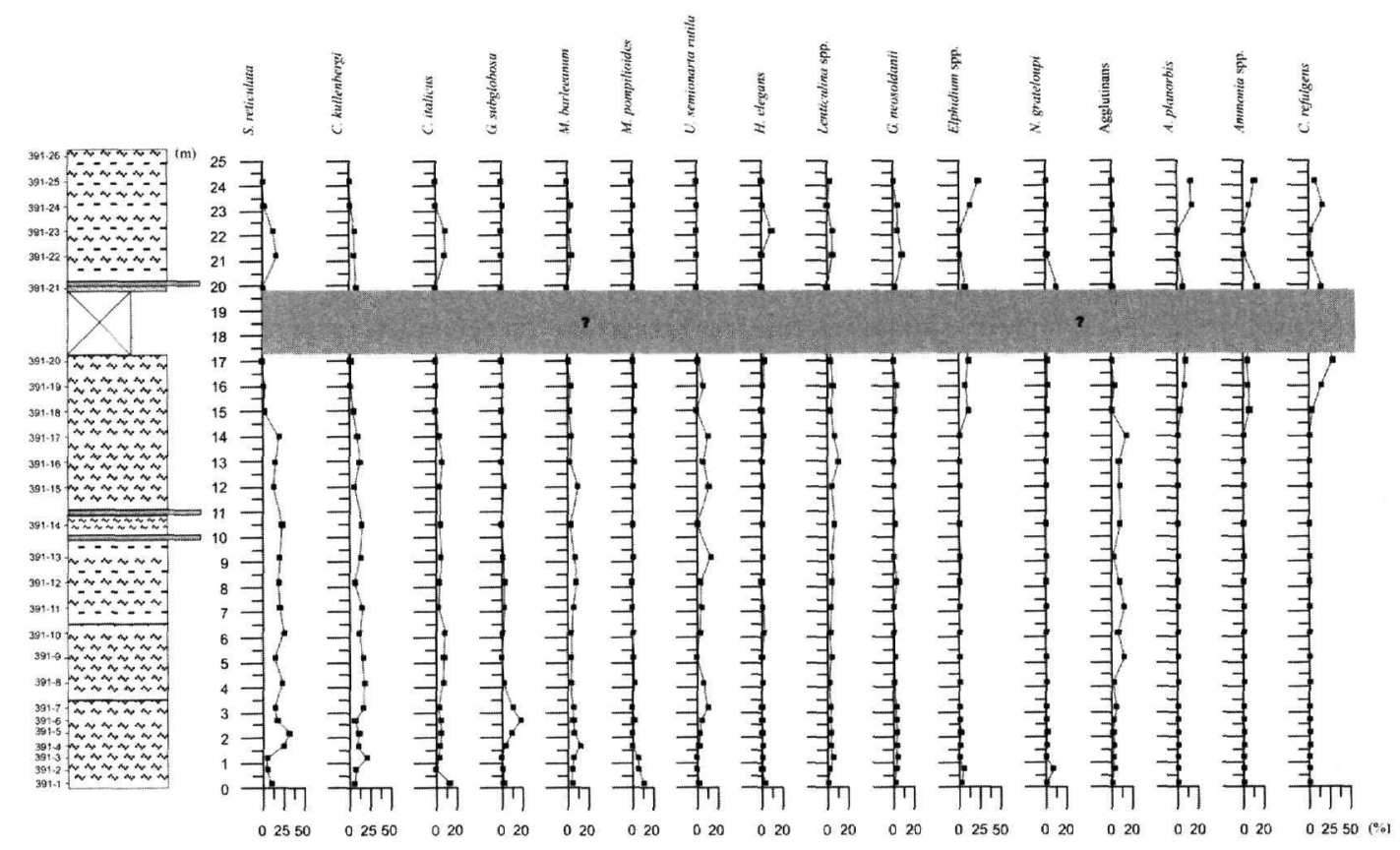

Figure 3 - Abundance pattern of the most significant benthic foraminifera species identified in the studied section
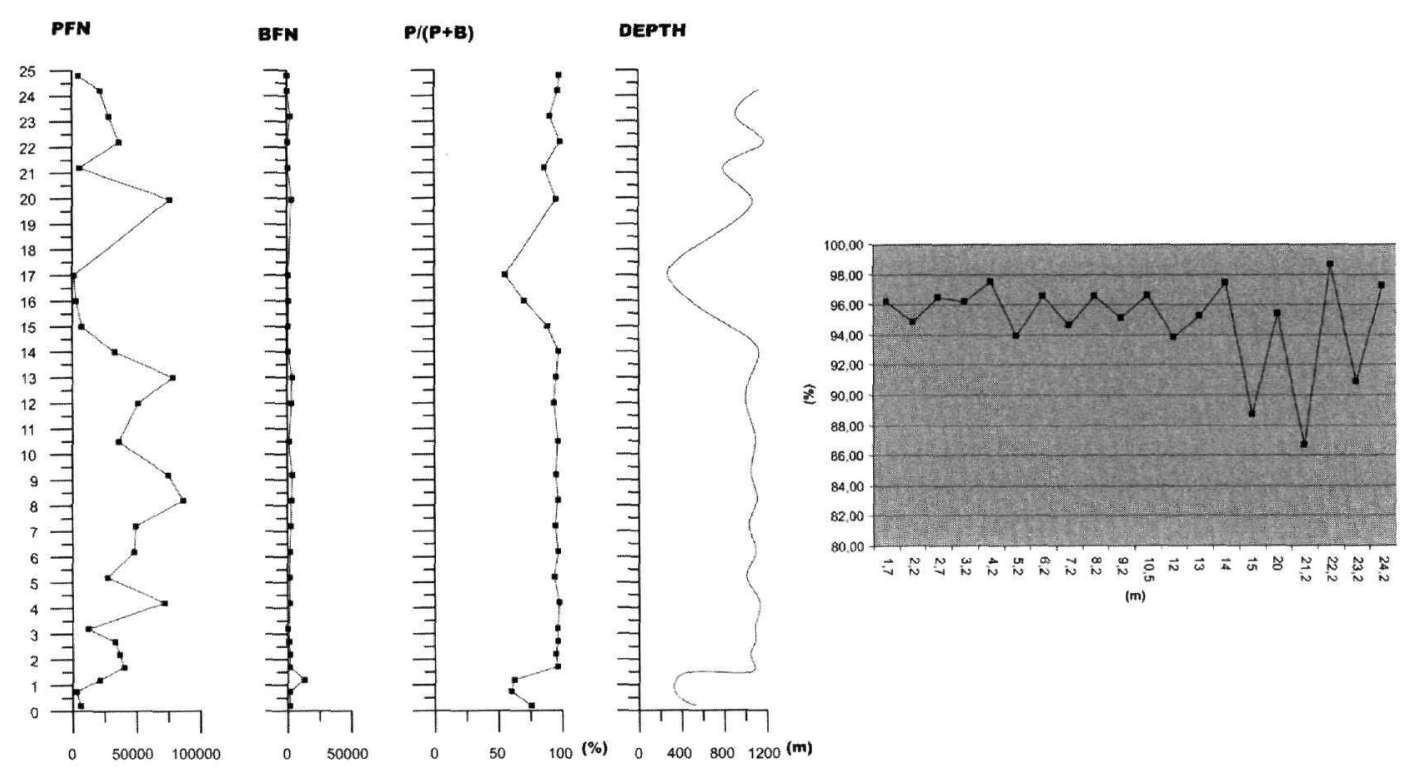

Figure 4 - PFN, BFN, P/B ratios together with the paleodepth curve obtained after the application of the regression of Van der Zwaan et al. (1990) of the studied samples. The inlet to the right represents variations in planktic percent above 90 exclusive three samples which show values below $60 \%$

Fig. 4 also shows planktic percentages of Manassi section samples exclusive of the four aforementioned samples. Several fluctuations are revealed by this graph. There is no relationship between these fluctuations and the sediment grain size as all the samples are from the grey marls. Although the significance of variations in planktic percent above $90 \%$ is problematical, this may 
merely reflect periodic dilution of the autochthonous deep-water fauna with transported shallower faunas (e.g. Robertson 1998). It is likely that, in these beds, some degree of faunal reworking has occurred, displacing shallow water taxa into deeper water faunas. This condition suggests that these beds could correspond to turbidite horizons.

In samples 391-1 to 391-3 and 391-20 there is a drop in P/B together with a drop in PFN. According to Speijer and Schmitz (1998), where fluctuations between these records coincide, it is likely that carbonate dissolution has occurred at some step during the generation of the fossil assemblage. In exceptional situations this association of changes may indicate a real paleoenvironmental change. If so, in shelf settings this should be readily discernable from the composition of the planktic and/or benthic foraminiferal assemblages.

Application of van der Zwaan et al. (1990) regression indicates that deposition began at $\sim 530 \mathrm{~m}$ (deep upper bathyal) during the deposition of sample 391-1 $(0.2 \mathrm{~m})$ and regressed to $\sim 340 \mathrm{~m}$ (upper bathyal) in sample 391-3 (1.2 m). The sea then transgressed to a paleodepth of $\sim 1130 \mathrm{~m}$ (deep lower middle bathyal) during the deposition of sample 391-17 (14 m). An ensuing rapid regression saw sea-levels attain a paleodepth $\sim 270 \mathrm{~m}$ (upper bathyal) during the deposition of sample $391-20$, then transgress abruptly to $\sim 1100 \mathrm{~m}$ (deep middle bathyal) at the time of sample 391-21 and remained relatively constant with short-term fluctuations from sample 391-22 till 39125.

\subsection{Diversity}

Shannon-Wiener $\mathrm{H}(\mathrm{S})$ values in the Manassi section vary from 2.61 to 3.42 (Table 1). Gibson and Buzas (1973) showed that these values correlate to water depths ranging from 80 to $3200 \mathrm{~m}$ in the northeastern Gulf of Mexico. In view of the wide ranges of water depths associated with diversity measure $\mathrm{H}(\mathrm{S})$, it is unrealistic to assign absolute water depths to Manassi deposition based on these criteria, although increasing diversity probably indicates increasing water depth in a relative sense. Therefore the variations in diversity may reflect only variations in degree of dilution by shallower water forms.

\subsection{Bathymetric significance of foraminiferal assemblages}

Any significant trends in palaeobathymetry can be independently checked on the studied samples along the succession, by identifying marker species for selected depth intervals.

The bathymetric preferences of the different foraminiferal taxa were assessed by evaluating their distribution pattern in modern oceans (Table 1). Based on this information the bathymetric evolution at the investigated site can be reconstructed. The paleodepths indicated by the benthic foraminifera in samples 391-4 to 391-18, 391-22 and 391-23 agree with those calculated using Van der Zwaan et al. (1990) regression. The benthic assemblages in these samples indicate an upper middle bathyal environment, being dominated by $C$. kullenbergi and $S$. reticulata. For samples $391-18$ to $391-21,391-24$ and 391-25, however, the paleodepths calculated from the percentage of planktic foraminiferal fauna differ markedly from those indicated by the benthic one. These samples yielded benthic assemblages that were dominated by Elphidium spp. and $C$. refulgens associated with a lesser A. planorbis and Ammonia spp. The normally shallow-water preferences of Elphidium species (Hayward et al. 1997) and C. refulgens (Murray 1991) suggest that these samples were deposited at neritic paleodepths and not at the bathyal paleodepths as suggested by the abundant planktic foraminifera. Furthermore, benthic foraminifera typical of deep-water habitats, such as were recorded in the lower part of the sequence, were also recovered from these samples, yet in small percentages. Thus the presence of specimens from Elphidium species and $C$. refulgens in fossil bathyal assemblages should be explained by sediment displacement (e.g Phleger et al. 1953) or rafting of plant material to which cibicidids lived attached into pelagic environments after storms (Sprovieri and Hasegawa 1990). 
Table 1- Depth distribution of a selection of benthic marker species based on Parker (1958), Blanc-Vernet (1969), Wright (1978), Parisi (1981), Jorissen (1987), Sprovieri and Hasegawa (1990), Sgarella and Moncharmont Zei (1993), De Stigter et al. (1998), De Rijk et al. (2000), Seidenkrantz et al. (2000), Jannink (2001), Kouwenhoven et al. (2003). Note that these studies are all based on the Mediterranean area

\begin{tabular}{|c|c|c|c|c|c|c|}
\hline Samples & $\begin{array}{c}\text { Predominant } \\
\text { Species }\end{array}$ & $\begin{array}{l}\text { Abundant } \\
\text { Species }\end{array}$ & Diversity & $\% \mathbf{P}$ & Depth & $\begin{array}{l}\text { Depth } \\
\text { (m) }\end{array}$ \\
\hline $391-1$ & C. italicus & $\begin{array}{l}\text { M. pompilioides } \\
\text { S. reticulata }\end{array}$ & 3,17 & 75,54 & $\begin{array}{c}\text { Deep } \\
\text { Upper } \\
\text { Bathyal } \\
\end{array}$ & 532,30 \\
\hline $391-2$ & C. kullenbergi & $\begin{array}{c}\text { A. helicinus } \\
\text { M. pompilioides }\end{array}$ & 3,41 & 60,00 & \multirow{2}{*}{$\begin{array}{l}\text { Upper } \\
\text { Bathyal }\end{array}$} & 332,23 \\
\hline $391-3$ & C. kullenbergi & & 3,07 & 62,05 & & 342,38 \\
\hline $391-4$ & S. reticulata & $\begin{array}{l}\text { C. kullenbergi } \\
\text { M. barleeanus }\end{array}$ & 2,88 & 96,22 & \multirow{14}{*}{$\begin{array}{c}\text { Deep } \\
\text { Lower } \\
\text { Bathyal }\end{array}$} & 1085,11 \\
\hline $391-5$ & S. reticulata & $\begin{array}{l}\text { C. kullenbergi } \\
\text { G. subglobosa }\end{array}$ & 2,67 & 94,90 & & 1043,03 \\
\hline $391-6$ & G. subglobosa & $\begin{array}{l}\text { S. reticulata } \\
\text { C. kullenbergi }\end{array}$ & 2,97 & 96,49 & & 1094,18 \\
\hline $391-7$ & C. kullenbergi & $\begin{array}{c}\text { S. reticulata } \\
\text { G. subglobosa } \\
\text { U. rutila }\end{array}$ & 2,83 & 96,21 & & 1090,81 \\
\hline $391-8$ & S. reticulata & C.kullenbergi & 2,75 & 97,50 & & 1131,74 \\
\hline $391-9$ & C. kullenbergi & S.reticulata & 3,03 & 93,91 & & 1010,36 \\
\hline $391-10$ & S. reticulata & C.kullenbergi & 2,68 & 96,54 & & 1096,30 \\
\hline $391-11$ & S. reticulata & C.kullenbergi & 3,1 & 94,65 & & 1033,51 \\
\hline $391-12$ & S. reticulata & C.kullenbergi & 3,12 & 96,57 & & 1108,00 \\
\hline $391-13$ & S. reticulata & $\begin{array}{l}\text { C.kullenbergi } \\
\text { U. rutila }\end{array}$ & 2,8 & 95,17 & & 1053,70 \\
\hline $391-14$ & S. reticulata & $\begin{array}{l}\text { C.kullenbergi } \\
\text { A. helicinus }\end{array}$ & 2,71 & 96,63 & & 1095,82 \\
\hline $391-15$ & S. reticulata & U. rutila & 3,32 & 93,84 & & 1005,78 \\
\hline $391-16$ & S. reticulata & $\begin{array}{l}\text { C.kullenbergi, } \\
\text { Lenticulina spp. }\end{array}$ & 2,99 & 95,24 & & 1047,53 \\
\hline $391-17$ & S. reticulata & $\begin{array}{c}\text { C.kullenbergi } \\
\text { U. rutila }\end{array}$ & 3,18 & 97,42 & & 1128,66 \\
\hline $391-18$ & Elphidium spp. & Ammonia spp. & 3,42 & 88,69 & Upper & 848,01 \\
\hline $391-19$ & C. refulgens & $\begin{array}{l}\text { Elphidium spp. } \\
\text { A. planorbis }\end{array}$ & 3,41 & 70,54 & Bathyal & 475,97 \\
\hline $391-20$ & C. refulgens & $\begin{array}{l}\text { Elphidium spp. } \\
\text { A. planorbis }\end{array}$ & 2,93 & 55,56 & $\begin{array}{l}\text { Upper } \\
\text { Bathyal }\end{array}$ & 274,82 \\
\hline $391-21$ & C. refulgens & Elphidium spp. & 2,79 & 95,39 & Deep & 1063,64 \\
\hline
\end{tabular}




\begin{tabular}{|c|c|c|c|c|c|c|}
\hline & & Ammonia spp. & & & \multirow{5}{*}{$\begin{array}{l}\text { Middle } \\
\text { Bathyal }\end{array}$} & \\
\hline $391-22$ & S. reticulata & $\begin{array}{l}\text { C. kullenbergi, } \\
\text { G. neosoldanii }\end{array}$ & 3,23 & 86,70 & & 793,49 \\
\hline $391-23$ & S. reticulata & $\begin{array}{c}\text { C. ungerianus, } \\
\text { H. elegans }\end{array}$ & 3,05 & 98,62 & & 1178,38 \\
\hline $391-24$ & C. refulgens & $\begin{array}{c}\text { Elphidium spp. } \\
\text { A. planorbis }\end{array}$ & 3,02 & 90,85 & & 914,46 \\
\hline $391-25$ & C. refulgens & $\begin{array}{l}\text { A. planorbis, } \\
\text { Ammonia spp. }\end{array}$ & 2,61 & 97,20 & & 1128,89 \\
\hline
\end{tabular}

\section{Discussion-Conclusions}

The present study was undertaken to provide a comprehensive paleobathymetric analysis of a section (Manassi section) located in the central part of the pre-Apulian Zone of Levkas Island. The biostratigraphic analysis based on planktic foraminifera indicated a Lower Tortonian age (between 11.54 and $11.21 \mathrm{Ma}$ ). This time interval is considered very crucial for the studied area as it marks the transition from carbonate to clastic sedimentation in western Greece and a phase of compression which affected the external Ionian zone and the pre-Apulian zone of Levkas. This shortening is related to the overriding of the pre-Apulian zone by the Ionian zone.

The paleobathymetric analysis showed that sedimentation occurred in a wide, deep and wellventilated foreland basin. Deposition occurred on a steep, unstable slope adjacent to a narrow shelf. Periodic downslope transport of shallow-water sediments into deeper water occurred throughout this interval, perhaps related to intense tectonic activity. The prominent occurrence of turbidite horizons can be linked to flysch deposition.

It has so far been generally accepted, that the Pre-Apulian zone lacks typical flysch sediments. However, we consider the post - Oligocene deposits as the distal atypical flysch sediments, deposited in the foredeep depozone of the most external domain (Pre-Apulian zone) of the Hellenides' foreland basin system (DeCelles and Giles 1996). Their partial absence in some areas is due to the fact that these areas correspond to the most external foreland basin forebulge uplifts, which sediments have possibly been eroded, leaving only unconformities.

\section{Acknowledgements}

This project is co-funded by the European Social Fund and National Resources (EPEAEK II) PYTHAGORAS II (70/3/8020).

\section{References}

Accordi, G., Carbone, F., and Pignatti, J., 1998. Depositional history of a Paleogene carbonate ramp (Western Cephalonia, Ionian Islands, Greece), Geol Romana, 34, 131-205

Aubouin, J., 1957. Essai de corrélation stratigraphique de la Grèce occidentale, Bulletin de la Societe Geologique de France, 7, 281-304

B.P., 1971. The geological results of petroleum exploration in Western Greece, I.G.S.R., 10, 1-73.

Bizon, G., 1967. Contribution à la connaissance des foraminifères planctoniques de l'Épire et des îles ioniennes (Grèce occidentale), Publication de l'Instititut Francais du Pétrole, Edition Technip, 1-44.

Blanc-Vernet, L., 1969. Contribution a l'étude des Foraminifères de Méditerranée, Recueil des Travaux de la Station Marine d'Endoume, 64, 1-281. 
Bornovas, J., 1964. Géologie de 1' île de Lefkade, Geol. and Geophys. Research (I.G.S.R.), 10, 142 pp.

Buzas, M.A., and Gibson, T.G., 1969. Species diversity: Benthonic foraminifera in western North Atlantic, Science, 163, 72-75.

Corliss, B.H., 1985. Microhabitats of benthic foraminifera within deep-sea sediments, Nature, 14, 435-438.

Caruso, A., Sprovieri, M., Bonnano, A., and Sprovieri, R., 2002. Astronomical calibration Serravallian-Tortonian Case Pelacani section (Sicily, Italy). In S.M. Iaccarino (ed.), Integrated Stratigraphy and Paleoceanography of the Mediterranean Middle Miocene. Rivista Italiana di Paleontologia e Stratigrafia, 108, 297-306pp.

Culver, S.J., 1988. New foraminiferal depth zonation of the Northwestern Gulf of Mexico, Palaios, 3, 69-86.

Cushing, M., 1985. Evolution structurale de la marge nord oust hellénique dans 1' île de Levkas et ses environs (Grèce nord occidentale), Thèse 3me cycle, Univ. De Paris-Sud.

De Mulder, E.F.J., 1975. Microfauna and sedimentary-tectonic history of the Oligo-Miocene of the Ionian Islands and Western Epirus (Greece), Utrecht Micropaleontol. Bul.l 13, 1-139.

De Rijk, S., Jorissen, F.J., Rohling, E.J., and Troelstra, S.R., 2000. Organic flux control on bathymetric zonation of Mediterranean benthic foraminifera, Marine Micropaleontology, $40,151-166$.

De Stigter, H.C., Jorissen, F.J., and Van der Zwaan, G.J., 1998. Bathymetric distribution and microhabitat partitioning of live (Rose Bengal stained) benthic foraminifera along a shelf to bathyal transect in the southern Adriatic Sea, Journal of Foraminiferal Research, 28, 4065 .

DeCelles, F.G., and Giles, K.A., 1996. Foreland basin systems, Basin Research, 8, 105-123.

Dermitzakis, M. D., 1978. Stratigraphy and sedimentary history of the Miocene of Zakynthos (Ionian Islands, Greece), Annales Geologique des Pays Helleniques, 29, 47-186.

Di Stefano, E., Bonomo, S., Caruso, A., Dinarés-Turell, J., Foresi, L., Salvatorini, G. and Sprovieri, R., 2002. Calcareous plankton bio-events in the Miocene Case Pelacani section (Southeastern Sicily, Italy). In S.M. Iaccarino (ed.), Integrated Stratigraphy and Paleoceanography of the Mediterranean Middle Miocene. Rivista Italiana di Paleontologia e Stratigrafia, 108, 307-324pp.

Duermeijer, C.E., Krijgsman, W., Langereis, C.G., Meulenkamp, J.E., Triantaphyllou, M.V., and Zachariasse, W.J., 1999. A Late Pleistocene clockwise rotation phase of Zakynthos (Greece) and implications for the evolution of the western Aegean arc, Earth Planet. Sci. Lett., 173, 315-331.

Ellis, B.F.S., and Messina, A.R., 1940. Catalogue of foraminifera, Am. Nat. Mus. N.Y. Spec. Publ.

Foresi, L.M., Bonomo, S., Caruso, A., Di Stefano, A., Di Stefano, E., Iaccarino, S. M., Lirer, F., Salvatorini, G., and Sprovieri, R., 2002. High resolution calcareous plankton biostratigraphy of the Serravalian succession of the Tremiti Islands (Adriatic Sea, Italy). In S.M. Iaccarino (ed.), Intergrated Stratigraphy and Paleoceanography of the Mediterranean Middle Miocene. Rivista Italiana di Paleontologia e Stratigrafia, 108, 257-273.

Gautier, P., Brun, J.-P., Moriceau, R., Sokoutis, D., Martinod, J., and Jolivet, L., 1999. Timing, kinematics and cause of Aegean extension: a scenario based on a comparison with simple analogue experiments, Tectonophysics, 315, 31-72. 
Gibson, T.G., and Buzas, M.A., 1973. Species Diversity: Pattern in modern and Miocene foraminifera of the eastern margin of North America, Geol. Soc. Amer. Bull., 84, 217-238.

Gooday, A.J., 1994. The biology of deep-sea foraminifera: a review of some advances and their applications in paleoceanography, Palaios, 9, 14-31.

Hayward, W.B., Grenfell, R.H., Pullin, D.A., Reid, C., and Hollis, J.C., 1997. Foraminiferal associations in the upper Waitemata Harbour, Auckland, New Zealand, Journal of the Royal Society of New Zealand, 27, 21-51.

Hilgen, F.J., Abdul Aziz, H., Krijgsman, W., Raffi, I., and Turco, E. 2003. Integrated stratigraphy and astronomical calibration of the Serravallian and lower Tortonian at Monte dei Corvi (Middle-Upper Miocene, northern Italy), Palaeogeography, Palaeoclimatology, Palaeoecology, 199, 229-264.

Hilgen, F.J., Krijgsman, W., Raffi, I., Turco, E., and Zachariasse, W.J., 2000. Integrated stratigraphy and astronomical calibration of the Serravallian/Tortonian boundary Section at Monte Gibliscemi (Sicily, Italy), Marine Micropaleontology, 38, 181-211.

Hilgen, F., Aziz, H.A., Bice, D., Iaccarino, S., Krijgsman, W., Kuiper, K., Montanari, A., Raffi, I, Turco, E., and Zachariasse, W.J., 2005. The global boundary stratotype section and point (GSSP) of the Tortonian stage (Upper Miocene) at Monte Dei Corvi, Episodes 28 (1), 6-17.

Iaccarino, S. 1985. Mediterranean Miocene and Pliocene planktic Foraminifera. In H.M. Bolli, J.B. Saunders and K. Perch-Nielsen (eds), Plankton Stratigraphy. Cambridge Univ. Press, London, 283-314pp.

Iaccarino, S. M., Lirer, F., Bonmo, S., Caruso, A., Di Stefano, A., Di Stefano, E., Foresi, L. M., Mazzei, R., Salvatorini, G., Sprovieri, R., and Turco, E., 2004. Astrochronology of Late Middle Miocene Mediterranean sections. In B. D' Argenio, A.G. Fischer, I. Premoli-Silva, H. Weissert and V. Ferreri (eds), Cyclostratigraphy: An Essay of Approaches and Case Histories, Society of Sedimentary Geology, 81, 25-42pp.

IGRS-IFP, 1966. Etude géologique de l' Epire (Grèce nord occidentale), Editions Technip, Paris, 306pp.

Jacobshagen, V., 1986. Geologie von Griechenland, Borntraeger, Berlin-Stuttgart, 279pp.

Jannink, N.T., 2001. Seasonality, biodiversity and microhabitats in benthic foraminiferal communities, Geologica Ultraiectina, 203, 192 pp.

Jorissen, F. J., de Stigter, H. C., and Widmark, J. G. V., 1995. A conceptual model explaining benthic foraminiferal microhabitats, Marine Micropaleontology, 26, 3-15.

Jorissen, F.J., 1987. The distribution of benthic foraminifera in the Adriatic Sea, Marine Micropaleontology, 12, 21-48.

Karakitsios, V., 1995. The Influence of Preexisting Structure and Halokinesis on Organic Matter Preservation and Thrust System Evolution in the Ionian Basin, Northwestern Greece, AAPG Bulletin, 79, 960-980.

Karakitsios, V., and Rigakis, N., in press. Evolution and Petroleum Potential of the Western Greece, Journal of Petroleum Geology.

Kouwenhoven, T.J., Hilgen, F.J., and Van der Zwaan, G.J., 2003. Late Tortonian-early Messinian stepwise disruption of the Mediterranean-Atlantic connections: constraints from benthic foraminiferal and geochemical data, Palaeogeography, Palaeoclimatology, Palaeoecology, 198, 303-319. 
Lirer, F., Caruso, A., Foresi, L.M., Iaccarino, S., and Iacumin, P., 2004. Paleoclimatic changes in the Serravallian record of the Mediterranean area. In R. Coccioni, S. Galeotti and F. Lirer (eds), Proceedings of the first Meeting of Environmental Micropaleontology for Young Italian Researcher, Grybowski Foundation Special Publication, 9, 77-96pp.

McDougall, K., 1985. Miocene to Pleistocene benthic foraminifers and paleoceanography of the Middle America slope, Deep Sea Drilling Project Leg 84, Initial Reports Deep Sea Drilling Project, 84, 363-418.

McKenzie, D.P., 1978. Some remarks on the development of sedimentary basins, Earth Planet. Sci. Lett., 40, 23-32.

Mendes, I., Gonzalez, R., Dias, J.M.A., Lobo, F., and Martins, V., 2004. Factors influencing recent benthic foraminifera distribution on the Guadiana shelf (Southwestern Iberia), Marine Micropaleontology, 51, 171-192.

Mirkou, R.M., 1974. Stratigraphie et Géologie de la partie septentrionale de l' île de Zante (Grèce), Ann. Géol.Pays Hell., 26, 35-108.

Murray, J. W., 1991. Ecology and Paleoecology of Benthic Foraminifera, Harlow, Essex, UK, Longman Scientific and Technical Publishers, $451 \mathrm{pp}$.

Murray, J.W., and Alve, E., 2000. Do calcareous dominated shelf foraminiferal assemblages leave worthwhile ecological information after their dissolution? In M.B. Hart, M.A. Kaminski and C.W. Smart (eds), Proceedings of the Fifth International Workshop on Agglutinated Foraminifera, Grzybowski Foundation Special Publication, 7, 311-331pp.

Nikolaou, C., 1986. Contribution to the study of Neogene and Geological concepts of the Ionian and Preapulian zone and their boundaries in relation to hydrocarbon exploration mainly on Strophades, Zakynthos and Cephallonia, PhD thesis, National and Kapodistrian University of Athens, 350 pp., Athens.

Parisi, E., 1981. Distribuzione dei foraminiferi bentonici nelle zone batiali del Tirreno e del Canale di Sicilia, Rivista Italiana di Paleontologia, 87 (2).

Parker, F.L., 1958. Eastern Mediterranean Foraminifera, Reports of the Swedish Deep-Sea Expedition, 8, 217-293.

Phleger, F.B., Parker, F.L., and Peirson, J.F., 1953. North Atlantic foraminifera. In H. Pettersson, (ed.), Reports of the Swedish Deep-Sea Expedition 1947-1948., Sediment cores from the North Atlantic, vol. VII. Fasc. 1, Sweden.

Robertson , B.E., 1998. Systematics and paleoecology of the benthic Foraminiferida from the Buff Bay section, Miocene of Jamaica, Micropaleontology, 44, 1-266.

Rondoyianni-Tsiambaou, Th., 1997. Les seismes et les environnement géologique de l' île de Lefkade, Grèce: Passé et futur. In Marinos et al. (eds), Engineering Geology and the Environment, Balkema, 1469-1474pp.

Schmiedl, G., Mackensen, A., and Müller, P.J., 1997. Recent benthic foraminifera from the eastern South Atlantic Ocean: dependence on food supply and water masses, Marine Micropaleontology, 32, 249-287.

Seidenkrantz, M.-S., Kouwenhoven, T.J., Jorissen, F.J., Shackleton, N.J., and Van der Zwaan, G.J., 2000. Benthic foraminifera as indicators of changing Mediterranean-Atlantic water exchange in the late Miocene, Marine Geology, 163, 387-407.

Sgarella, F., and Moncharmont Zei, M., 1993. Benthic foraminifera of the Gulf of Naples (Italy): systematics and autoecology, Bolletino della Societa Paleontologica Italiana, 32 145-264. 
Speijer, R.P., and Schmitz, B., 1998. A benthic foraminiferal record of Paleocene sea level and trophic/redox conditions at Gebel Aweina, Egypt, Palaeogeography, Palaeoclimatology, Palaeoecology, 137, 79-101.

Sprovieri, R., and Hasegawa, S., 1990. Plio-Pleistocene Benthic foraminifer stratigraphic distribution in the deep-sea record of the Tyrrhenian sea (ODP LEG 107), Proceedings of the Ocean Drilling Program, Scientific Results, 107, 429-459.

Van der Zwaan, G.J., Jorissen, F.J., and De Stigter, H.C., 1990. The depth dependency of planktic/benthonic foraminiferal ratios: constraints and applications, Mar. Geology, 95, 116.

Van Hinsbergen, D.J.J., Kowenhoven, T.J., and Van der Zwaan, G.J., 2005a. Paleobathymetry in the backstripping procedure: correction for oxygenation effects on depth estimates, Palaeogeography, Palaeoclimatology, Palaeoecology, 221, 245-265.

Wright, R., 1978. Neogene paleobathymetry of the Mediterranean basen on benthic foraminifers from DSDP leg 42A. In K.J. Hsü and L. Montadert et al., (eds), Initial Reports of the Deep Sea Drilling Project, Scripps. Inst. Oceanogr. 837-846. 